\title{
Synthesis of Five Membered Heterocycles Using Microwaves Technique
}

\author{
Moayed S. AL. Gawady \\ Deptartment of Chemistry \\ College of Science \\ Mosul University \\ E-mail: algwady59@yahoo.com
}

(Received 28/4/2010; Accepted 13/7/2010)

\begin{abstract}
A series of $\mathrm{N}$-(5-substituted 1,3,4-thiadiazol-2-yl maleimides (14-18) were prepared by cyclization of corresponding maleamic acids (7-12). These acids were prepared by the reaction of 2-amino-5-aryloxymethyl-1,3,4-thiadiazoles (1-6) with maleic anhydride. The starting amines (1-6) were prepared from different aryloxyacetic acids and thiosemicarbazide .

The structure of the prepared compounds was suggested in the light of IR and UV Spectroscopy.
\end{abstract}

Key words: Maleimides; 1,3,4-Thiadiazoles; Microwave synthesis

\section{تشسيدمركبل خملسية الحلفة غيرمتجلنة بلستخدلم قنية الميكروفف}

\section{الملغص}

مُ تحضيرسلسلة من N - 5 معوض-4،3،1 - ثايادايازولات الماليميدات (14-14) بوسطلة حوقلة حولمض المالميدات المقابلة (7-12). حضرت هذه الحولمض من تقاعل مركبلت 2 -المينو -5 - اريلوكسه مثيل

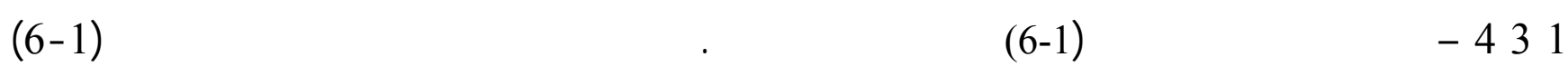
فقد حضرت من تفاعل عدد من مركبلت الاريلوكسى حلمض الخليك مع الثايوسيه كاربازيد. قم إقتراح الترلكيب الكيميائية للمركبلت فى ضوء فطيفية الأشعة تهت الحمراء وفوق البفنجية.

\section{INTRODUCTION}

Several procedures were reported for the synthesis of 2-amino-1,3,4-thiadiazoles, in many of these methods a thiosemicarbazide was the starting material which first acylated to 1acylthiosemicarbazide (Saied, 1983) which cyclized with a suitable dehydrating agents such as phosphorus pentachloride (Rabjohn et al., 1973 and Kulchitskaya et al., 1956), phosphorous 
oxychloride and thionyl chloride (Rabjohn et al., 1973 and Kretov et al., 1956). Acylation and cyclization could be achieved in a one step reaction by heating an acyl halide, or even a carboxylic acid with a thiosemicarbazide in the presence of phosphorous acid or concentrated sulfuric acid (Saied, 1983).

These heterocyclic amines were used as synthon in synthesis of cyclic amides by their reaction with cyclic anhydrides via intermediate maleamic acid (Rabjohn et al., 1973 ). Many dehydrating agents such as phosphorus pentachloride (Rabjohn et al., 1973 and Kretov et al., 1956), phosphorous oxychloride and thionyl chloride were used to cyclize these intermediates (Kretov et al., 1956).

The pyrolysis accompanied by a number of undesirable products (Saied, 1983) in addition to long reaction times and complications of materials handling were the causes of low yield of these thiadiazoles (Al-Gwady; 2007) .

Because microwave heating had emerged as a powerful technique to promote a variety of chemical reactions, recent applications were used this technology in hetero ring cyclization and in many important reactions (Katritzky and Singh, 2003; Tierney and Westman, 2001 ; Tanaka and Toda, 2000).

As part of continuous program directed toward the synthesis of important heterocyclic compounds, oxygenous and nitrogenous five and six membered rings (Shandala et al., 1998); (Shandala et al., 2001) (Shandala et al., 2002) and (Ayoub et al., 2001), it was become of interest to investigate preparative routs to synthesize N-substituted 1,3,4- thiadiazolyl maleimides due to their immunosuppressive properties which were studied by measuring their ability to inhibit nitrogen-induced leukemia-cell by reaction with more cellular thiols (Freed et al., 1999).

\section{EXPERIMENTAL}

All melting points were determined on a Gallen Kamp and Electro thermal 1A9300 Digital-Series 1998 apparatus and were uncorrected. The IR - spectra $\left(v \mathrm{~cm}^{-1}\right)$ were recorded on Perkin - Elmer 590B Spectrophotometer. UV-1650, Shimadzu PC Spectrophotometer using methanol as solvent. Thin layer chromatography (T.L.C.) was carried out on silica gel coated plate type linear-KL, Whatman com.

\section{2-Amino-5-aryloxymethyl - 1,3,4 -thiadiazoles (1-6):}

Method (a) (conventional procedure): (Saied, 1983)

Phosphorous oxychloride $4.6 \mathrm{~g}$ was added drop-wise to an ice cooled mixture of ( $0.9 \mathrm{gm}$, 0.01 mole) thiosemicarbazide and 0.01 mole of the proper aryloxyacetic acid with shaking. The reaction mixture was refluxed for an hour, then cooled to room temperature, and added to $250 \mathrm{ml}$ of stirred ice-cold water then neutralized with $10 \%$ sodium carbonate solution. The cyclized product that precipitated was filtered, washed with water and crystallized from aqueous ethanol. Purity of compounds was established by a single spot in TLC. Melting points, yields and IR spectral data of compounds (1-6) were listed in Table (1). 
Method (b) (microwave irradiation): (Saied,2007)

Phosphorous oxychloride $1 \mathrm{~g}$ was added drop-wise to an ice-cooled mixture of $(0.9 \mathrm{~g}, 0.1$ mole) thiosemicarbazide and 0.01 mole of the proper aryloxyacetic acid with shaking. The reaction mixture was irradiated for 3 minutes in $210 \mathrm{~W}$ domestic microwave oven, and it was then worked up as in method (a).

Table 1: Melting points, yields and IR spectral data of compounds (1-6).

\begin{tabular}{|c|c|c|c|c|c|c|c|c|c|c|c|}
\hline \multirow[b]{2}{*}{$\begin{array}{c}\text { Compd } \\
\text { No. }\end{array}$} & \multirow[b]{2}{*}{$\mathbf{X}$} & \multirow[b]{2}{*}{$\mathbf{Y}$} & \multirow[b]{2}{*}{$\underset{{ }_{0}}{\text { M.P. }}$} & \multicolumn{2}{|c|}{$\begin{array}{l}\text { Yield \% } \\
\text { method }\end{array}$} & \multicolumn{5}{|c|}{$\begin{array}{l}\text { IR v cm } \\
\mathrm{KBr} \operatorname{disc}\end{array}$} & \multirow{2}{*}{$\begin{array}{c}\text { UV } \\
\lambda \mathbf{m a x} \\
(\mathbf{n m}) \\
\mathrm{MeOH}\end{array}$} \\
\hline & & & & $\mathbf{a}$ & $\mathbf{b}$ & $\begin{array}{c}\text { Aromatic } \\
\text { C-H } \\
\text { bending }\end{array}$ & $\begin{array}{c}\text { N-H } \\
\text { Stretching } \\
\text { and } \\
\text { Bending } \\
\end{array}$ & $\mathrm{C}-\mathrm{O}-\mathrm{C}$ & $\begin{array}{c}\text { Ring } \\
\mathrm{C}=\mathrm{N} \text { \& } \\
\mathrm{C}=\mathrm{C} \text { stretching }\end{array}$ & Others & \\
\hline 1 & $\mathrm{H}$ & $\mathrm{H}$ & $198-200$ & 40 & 80 & 750 & $\begin{array}{l}3100 \\
1650 \\
\end{array}$ & 1220 & $1595 ; 1520$ & - & 240 \\
\hline 2 & $\mathrm{Cl}$ & $\mathrm{H}$ & $204-5$ & 44 & 88 & 830 & $\begin{array}{l}3300 \\
1590 \\
\end{array}$ & 1200 & $1595 ; 1520$ & - & 240 \\
\hline 3 & $\mathrm{Cl}$ & $\mathrm{Cl}$ & $167-8$ & 50 & 90 & 850 & $\begin{array}{l}3150 \\
1590 \\
\end{array}$ & 1160 & $1600 ; 1520$ & - & 255 \\
\hline 4 & $\mathrm{Br}$ & $\mathrm{Br}$ & $157-8$ & 40 & 85 & 850 & $\begin{array}{l}3150 \\
1590\end{array}$ & 1166 & $1595 ; 1520$ & - & 260 \\
\hline 5 & $\mathrm{~F}$ & $\mathrm{H}$ & 209-10 & 30 & 85 & 760 & $\begin{array}{l}3100 \\
1590 \\
\end{array}$ & 1190 & $1595 ; 1520$ & - & 260 \\
\hline 6 & $\mathrm{NO}_{2}$ & $\mathrm{H}$ & 210-11 & 40 & 84 & 750 & $\begin{array}{l}3300 \\
1560\end{array}$ & 1200 & $1600 ; 1520$ & $\begin{array}{l}1510 \\
1345 \\
\mathrm{NO}_{2} \\
\end{array}$ & 270 \\
\hline
\end{tabular}

N-(2-Amino-5-aryloxymethyl-1,3,4-thiadiazol-2-yl) maleamic acids (7-12): (El-Emam and Lehmann, 1994) and (Rabjohn, 1973).

In a three-necked flask provided with a paddle type stirrer, a reflux condenser and a dropping funnel, (9.8 gm, 0.1 mole) of maleic anhydride and $100 \mathrm{ml}$ of ethanol was placed. When the entire compound was dissolved by stirring, a solution of $(0.1 \mathrm{~mole})$ of appropriate amine (1-6) in $20 \mathrm{ml}$ of dimethyl formamide was run dropwise through the dropping funnel. The resulting thick suspension was stirred at room temperature for one hour and was then cooled to $15-20{ }^{\circ} \mathrm{C}$ in an ice bath. The product was obtained by suction filtration, and treated with $5 \%$ solution of sodium carbonate, filtered and acidified with dilute hydrochloric acid.

The precipitate was filtered, washed with cold water, and dried in oven at $\left(100{ }^{\circ} \mathrm{C}\right)$, then recrysytallized from ethanol. Melting points, yields and IR spectral data of compounds (7-12) were listed in Table (2). 
N-(2-Amino-5-aryloxymethyl-1,3,4-thiadiazol-2-yl) maleimides (13-18): Method (c) (conventional procedure): (El-Emam and Lehmann, 1994).

Appropriate maleamic acid ( 0.05 mole $)$ was dissolved in $2 \mathrm{ml}$ dimethyl formamide. To this solution $(0.1$ mole $)$ phosphorous pentoxide was added. The mixture was heated at $70-80{ }^{\circ} \mathrm{C}$ for two hours.

After cooling to room temperature and evaporating of the solvent, the solid material was crushed well and washed with 5\% sodium carbonate solution to dissolve the un-reacted maleamic acid. The precipitate was filtered off, washed well with water and dried in oven at $\left(100{ }^{\circ} \mathrm{C}\right)$ to give the crude maleimide, which was purified by recrystallization from DMF . Purity of compounds was established by a single spot in TLC. Melting points, yields and IR spectral data of compounds (13-18) were listed in Table (3).

Method (d) (microwave irradiation): (El-Emam and Lehmann, 1994) and (Rabjohn, 1973).

Appropriate maleamic acid ( 0.05 mole) was irradiated for 12 minutes in $210 \mathrm{~W}$ microwave oven. The resulting liquid, which solidified when cooled, was worked up as in method (c).

Table 2: Melting points, yields and IR spectral data of compounds (7-12).

\begin{tabular}{|c|c|c|c|c|c|c|c|c|c|c|}
\hline \multirow{2}{*}{$\begin{array}{c}\text { Compd. } \\
\text { No. }\end{array}$} & \multirow[b]{2}{*}{$\mathbf{X}$} & \multirow[b]{2}{*}{$\mathbf{Y}$} & \multirow{2}{*}{$\underset{{ }^{\circ} \mathrm{C}}{\mathrm{M} . P .}$} & \multirow{2}{*}{$\begin{array}{c}\text { Yield } \\
\%\end{array}$} & \multicolumn{5}{|c|}{$\begin{array}{l}\text { I.R v cm }{ }^{-1} \\
\text { KBr disc }\end{array}$} & \multirow{2}{*}{$\begin{array}{c}\mathbf{U V} \\
\lambda \max (\mathbf{n m}) \\
\mathbf{M e O H}\end{array}$} \\
\hline & & & & & $\begin{array}{l}\mathrm{C}=\mathbf{O} \\
\text { acid }\end{array}$ & $\begin{array}{c}\mathrm{C}=\mathrm{O} \\
\text { amide }\end{array}$ & C-O-C & $\mathbf{C}=\mathbf{N}$ & others & \\
\hline 7 & $\mathrm{H}$ & $\mathrm{H}$ & $190-2$ & 40 & 1250 & 1608 & 1170 & 1220 & - & 290 \\
\hline 8 & $\mathrm{Cl}$ & $\mathrm{H}$ & $185-7$ & 44 & 1250 & 1608 & 1170 & 1220 & - & 300 \\
\hline 9 & $\mathrm{Cl}$ & $\mathrm{Cl}$ & $156-7$ & 50 & 1300 & 1620 & 1160 & 1220 & - & 310 \\
\hline 10 & $\mathrm{Br}$ & $\mathrm{Br}$ & $138-140$ & 40 & 13000 & 1610 & 1166 & 1200 & - & 310 \\
\hline 11 & $\mathrm{~F}$ & $\mathrm{H}$ & $196-8$ & 30 & 1270 & 1620 & 1190 & 1200 & - & 310 \\
\hline 12 & $\mathrm{NO}_{2}$ & $\mathrm{H}$ & $200-202$ & 40 & 1300 & 1620 & 1166 & 1220 & $\begin{array}{c}1510 \\
1345 \\
\left(\mathrm{NO}_{2}\right)\end{array}$ & 290 \\
\hline
\end{tabular}


Table 3: Melting points, yields and IR spectral data of compounds (13-18)

\begin{tabular}{|c|c|c|c|c|c|c|c|c|c|c|}
\hline \multirow{2}{*}{$\begin{array}{c}\text { Compd. } \\
\text { No. }\end{array}$} & \multirow{2}{*}{$\mathbf{X}$} & \multirow{2}{*}{$\mathbf{Y}$} & \multirow{2}{*}{$\underset{{ }^{\mathbf{M}} \mathrm{C}}{\mathrm{M} . P .}$} & \multicolumn{2}{|c|}{$\begin{array}{l}\text { Yield,\% } \\
\text { Method }\end{array}$} & \multicolumn{4}{|c|}{$\begin{array}{c}\text { I.R } \\
v \mathrm{~cm}^{-1} \\
\mathrm{KBr} \operatorname{disc}\end{array}$} & \multirow{2}{*}{$\begin{array}{c}\text { UV } \\
\lambda \underset{\max (n m)}{\operatorname{MeOH}}\end{array}$} \\
\hline & & & & c & d & $\begin{array}{c}\mathrm{C}=\mathbf{O} \\
\text { Imide }\end{array}$ & $\mathbf{C}=\mathbf{N}$ & C-O-C & Others & \\
\hline 13 & $\mathrm{H}$ & $\mathrm{H}$ & $144-5$ & 56 & 85 & 1690 & 1595 & 1170 & - & 334 \\
\hline 14 & $\mathrm{Cl}$ & $\mathrm{H}$ & $150-3$ & 56 & 89 & 1690 & 1590 & 1170 & $\begin{array}{l}- \\
-\end{array}$ & 334 \\
\hline 15 & $\mathrm{Cl}$ & $\mathrm{Cl}$ & $130-3$ & 50 & 84 & 1700 & 1595 & 1160 & - & 340 \\
\hline 16 & $\mathrm{Br}$ & $\mathrm{Br}$ & $155-2$ & 45 & 85 & 1720 & 1590 & 1166 & - & 340 \\
\hline 17 & $\mathrm{~F}$ & $\mathrm{H}$ & $145-6$ & 45 & 80 & 1720 & 1590 & 1190 & - & 340 \\
\hline 18 & $\mathrm{NO}_{2}$ & $\mathrm{H}$ & $152-3$ & 44 & 84 & 1700 & 1590 & 1166 & $\begin{array}{l}1510 \\
1345 \\
\left(\mathrm{NO}_{2}\right) \\
\end{array}$ & 340 \\
\hline
\end{tabular}




\section{RESULTS AND DISCUSSION}

Scheme (1) summarized the synthetic route for the preparation of the designed compounds.

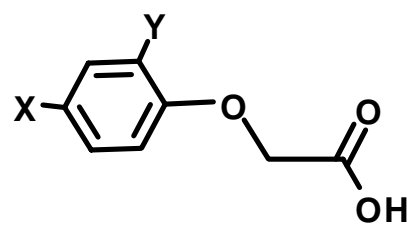

$$
\mid \mathrm{H}_{2} \mathrm{~N}-\mathrm{NH}-\mathrm{CS}-\mathrm{NH}_{2}
$$

(a): Conventional $\mathrm{POCl}_{3}$, reflux 60 minutes

(b) : $\mathrm{POCl}_{3}, \mathrm{MW}(210 \mathrm{~W}), 3$ minute
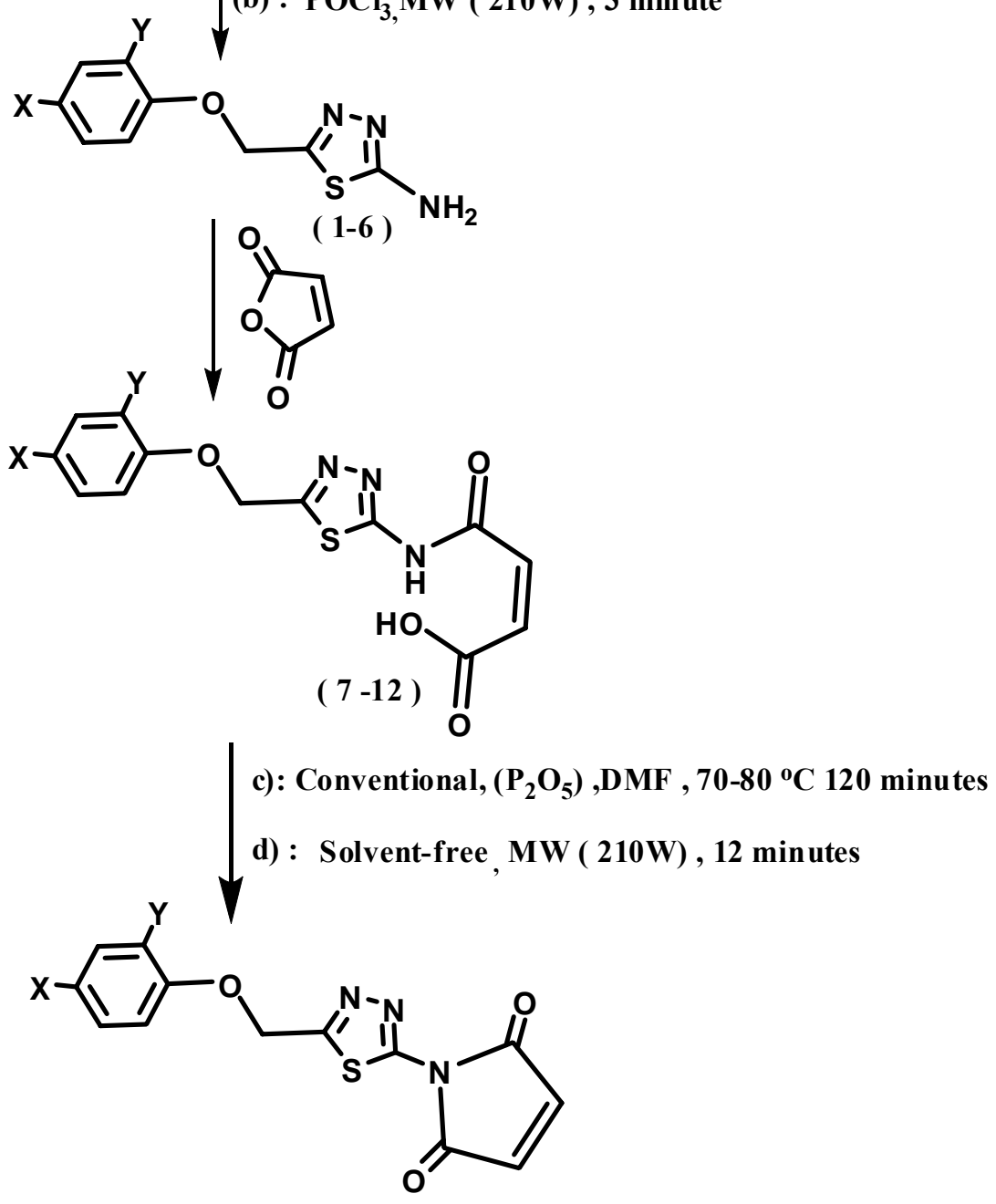

(13-18)

Scheme ( 1 )

$\mathrm{X}$ and $\mathrm{Y}$ are given in Tables (1-3) 
2-Amino-5-aryloxymethyl-1,3,4-thiadiazoles (1-6) were prepared via a one step acylation and cyclization of carboxylic acid with a thiosemicarbazide in the presence of phosphorous oxychloride as shown in Scheme (2) (Al-Gawady , 2009) and (Zheng Li et al., 2005).

Two different procedures were used, in method (a), a conventional procedure in which large amounts of phosphorous oxychloride are used to give (30 -50\%) yield in one hour (Saied, 1983).

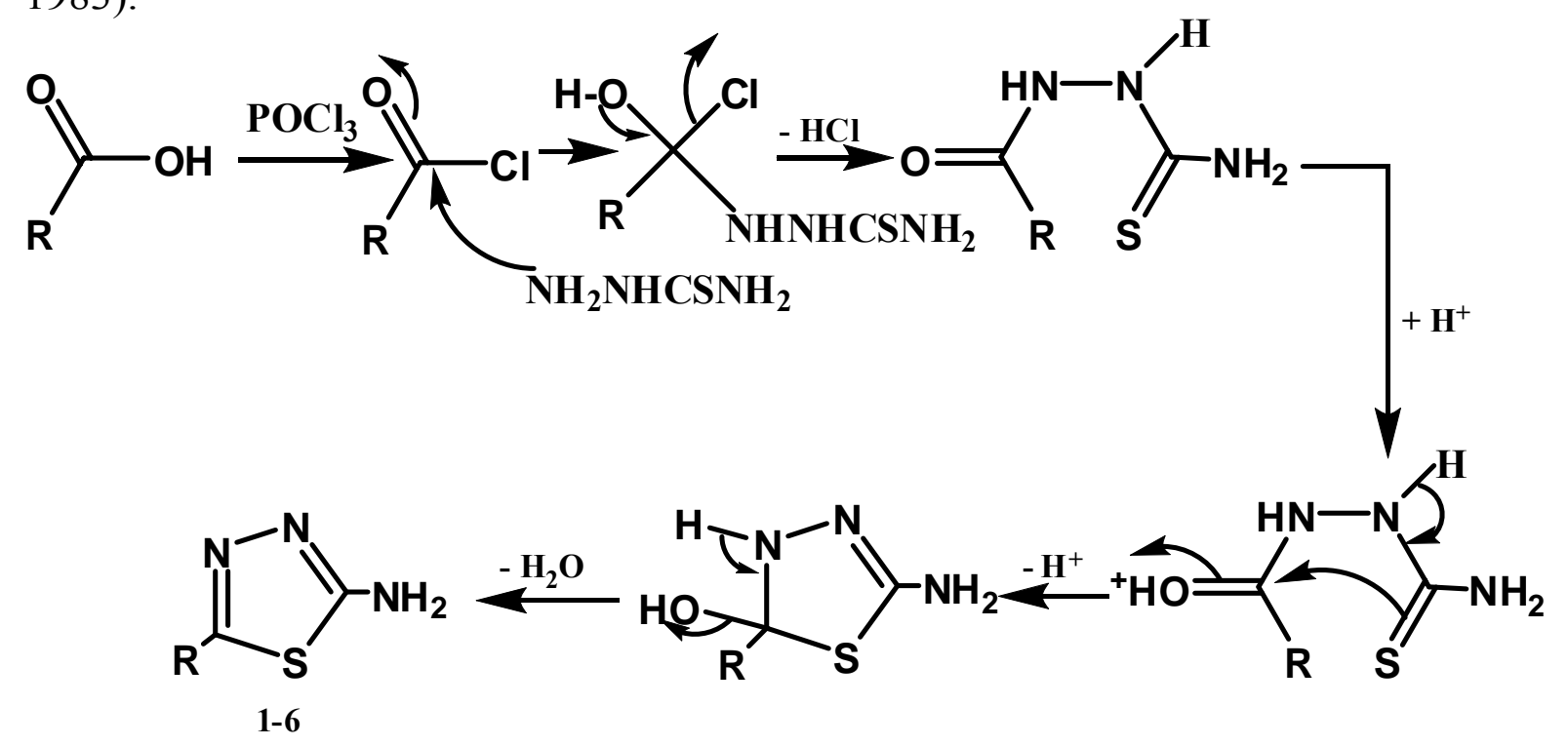

$$
\begin{gathered}
\text { Scheme (2) } \\
\mathrm{R}=\mathrm{C}_{6} \mathrm{H}_{5} ; 4-\mathrm{Cl}-\mathrm{C}_{6} \mathrm{H} 4-; 2,4-(\mathrm{Cl})_{2}-\mathrm{C}_{6} \mathrm{H}_{3}-; \\
2,4-(\mathrm{Br})_{2}-\mathrm{C}_{6} \mathrm{H}_{3}-; 4-\mathrm{F}-\mathrm{C}_{6} \mathrm{H}_{4} \text { - or 4- } \mathrm{NO}_{2}-\mathrm{C}_{6} \mathrm{H}_{4} \text { - respectively }
\end{gathered}
$$

While in method (b), the microwave irradiation for 3 minutes in present of small amounts of dehydrating agent (only one gram of $\mathrm{Ca} \mathrm{SO}_{4}$ ) was used to give the highest yield (80-90\%) (ElEmam and Lehmann, 1994) and (Rabjohn, 1973). Here the microwave radiation accelerated solvent-free cyclization (Zheng Li et al., 2005).

The disappearance of $\mathrm{C}=\mathrm{O}$ stretching in IR spectra was good indication of conversion of acid to heteroring, in addition to the following frequencies: $3100-3300 \mathrm{~cm}^{-1}$ and $1560-1590 \mathrm{~cm}^{-}$ ${ }^{1}$ due to $\mathrm{NH}$ stretching and bending respectively, $1595-1600 \mathrm{~cm}^{-1}$ for $\mathrm{C}=\mathrm{N}$ stretching, and $1520 \mathrm{~cm}^{-1}$ for $\mathrm{C}=\mathrm{C}$ ring stretching, Table (1). The UV spectra showed absorption peaks at $\lambda \max 240-270 \mathrm{~nm}$ for $\left(\mathrm{n} \rightarrow \pi^{*}\right)$ electronic transitions.

N- (2-Amino-5-aryloxymethyl-1,3,4-thiadiazol-2-yl) maleamic acids (7-12) were prepared by treatment of primary amines with maleic anhydride (El-Emam and Lehmann, 1994). These acids were identified by IR spectra which showed two carbonyl absorption bands, one for the acid carbonyl at $\left(1250-1300 \mathrm{~cm}^{-1}\right)$ and the other for amide carbonyl at $\left(1608-1620 \mathrm{~cm}^{-1}\right)$. The increase in the values $\lambda \max$ in the spectra of these compounds about $(20-40 \mathrm{~nm})$ relatives $\lambda \max$ of compounds (1-6) was due to the first $\pi \rightarrow \pi^{*}$ transition bands shift of acid conjugation effect. 
N-(2-Amino-5-aryloxymethyl - 1,3,4 -thiadiazol-2-yl) maleimides (13-18) were prepared using a conventional procedure (c) to yield (44 -56\%) during two hours heating in DMF solvent, while the solvent free microwave-assisted procedure (d) gave yield (80-89\%) through only twelve minutes irradiation time. The driving force for these rings formation was the water elimination in the last step (Al-Gwady, 2009). These compounds were assigned from their IR and UV spectra which came in agreement with the published data (Matsuo, 1964).

Imides (13-18) showed characteristic absorption bands in the $1690-1710 \mathrm{~cm}^{-1}$ region of their IR spectra, Table (3), these two bands come from a mechanical coupling of the two carbonyl groups in acid anhydrides (Matsuo, 1964). The increase in the values $\lambda$ max in the spectra of these compounds about $(64-66 \mathrm{~nm})$ due to the $\pi \rightarrow \pi^{*}$ transition due to ring system.

\section{REFERENCES}

Al-Gwady , M. N. (2007). "A Comparative Studies Between Microwave and Conventional Techniques Using Different Catalysts to Synthesize New Isobenzofurns". 10th scientific conference for foundation of technical education Baghdad; 142; 28-29, Baghdad; April.

Al-Gwady, M. N. (2009). Synthesis of 2-Amino-5-substituted -1,3,4-thiadiazoles ATDA) and their Derivatives Using Conventional and Microwave Techniques. J. Raf. Sci., 20(1), 1 .

Ayoub, M.T ; Shandala, M.Y.; Al-Mukhtar, S.E.; Noori, M.S. (2001). Brigehead nitrogen heterocyclic: Synthesis of Fused Heterocyclics from 3- substituted methyl-1,3,4triazole-5-thion (part iv). J. Raf. Sci., 12( 4), 19-28.

El-Emam, A. A. ; Lehmann, J. (1994). Adamantane derivatives IV: Unexpected debenzylation on ring closure of 1-(1-adamantylcarbonyl)-4- benzylthiosemicarbazide with sulphuric acid. Monatsbefte fur Chemic. 125, 587-591.

Freed, B.F.; Lempert, N. ; Lawrence, D. A. (1999). "Inhibition of Interleukin-2 Production in the Human T Cell Line JURKAT by Nonpolar Maleimides". Transplantation Immunology Laboratory, Department of Surgery, Albany Medical College, Albany, NY 12208, U. S .

Jassim, A. J. (1997). Synthesis of novel phenol formaldehyde resins containing pendant isoimides and their isomerization to the corresponding stable imides copolymerization of some $\mathrm{N}$-substituted maleimides with sodium styrene sulfonate. PhD. Thesis, Department. of Chemistry, College of Science, Baghdad University, Iraq.

Katritzky, A. R.; Singh, S. K. (2003). "Microwave-assisted Heterocyclic Synthesis", ARKIVOC (xiii) 68-86. Kretov, A. F. and Kulchitskaya, N.A.; (1956); Zh. Obsch Khim. 26, 208.

Matsuo, T. (1964). Carbonyl absorption bands in the infrared spectra of some cyclic imides with a five-membered ring. Bulletin Chem. Soc. Japan. 37 (12), 1844-1848.

Rabjohn, N. (1973). "Organic Synthesis Collective".,vol.3. John Wiley and Sons , Inc., 944.

Saied, S. M. (1983). Synthesis of some heterocyclic derivatives of anticipated insecticidal activity. M.Sc. Thesis, College of pharmacy, University of Baghdad, Iraq . 
Saied , Sh. M. (2007) "Synthesis and hypoglycemic activity of N-new 5-(1,1-diphenyl-1hydroxymethyl)-substituted oxa/thiadiazoles sulfonamides". $10^{\text {th }}$ scientific conference for foundation of technical education Baghdad .

Shandala, M. Y.; Ayoub , M.T.; Noori, M. S. (2001). Synthesis of some new substituted thiosemicarbazides and their corresponding 1,2,4-triazole; 1,3,4-thiadiazoles and 1,3,4-oxadiazole (part iii). J. Raf. Sci, 1, 3-9.

Shandala, M.Y.; Ayoub , M.T.; Noori, M.S. (2002). Synthesis of 5-substituted- 1,3,4oxadiazoline-2-thiones and related compounds derived from diphenyl acetic acid (part ii). J. Raf. Sci, Chemistry Special Issue,1.

Tanaka , K. ; Toda, F. (2000). Solvent-free organic synthesis. Chem. Rev. 100, 1025.

Shandala, M.Y.; Ayoub , M. T.; Noori, M. S. (1998). Benzilic acid as synthon in synthesis of some new polyfunctional subsistuted 1,3,4-oxadiazole and 1,2,3-triazozole(Part1). $J$. Raf. Sci, 9(2), 34-39.

Tierney, J. ; Wathey, A.; Westman, J. (2001). Microwave Assisted Organic Synthesis. Tetrahedron; 57, 9225-9283.

Zheng, Li. ; Jinlan, Yu.; Runbo Ding; Zhiyuan W.; Xicun W. (2005). Microwave accelerated solvent-free synthesis of 1,3,4-oxadiazoles using polymer supported dehydration reagent. Synthetic Communications, 34(16), 2981 - 2986. 